\title{
Index of the state of reliability of the heat supply system on the example of an individual residential building
}

\author{
Sergey Guzhov*, Anton Sofronitsky, and Tatyana Andreeva \\ National Research University "Moscow Power Engineering Institute", Moscow, Russia
}

\begin{abstract}
The development of scientific and technological progress has led to the creation of many technical solutions for implementation in the heat supply system. Such solutions, as a rule, are energy-saving, automated, and are positioned by manufacturers as a quick payback. Over time, the cost of such technologies decreases to a level acceptable to most citizens. The introduction of inexpensive energy-saving technologies is becoming more and more widespread. Heat supply systems for even small buildings are becoming more and more complex and device-rich. Modern technologies that are energy-saving include, for example: a heat pump with the extraction of thermal energy from the ground; heat pump with the intake of heat energy from the outside air; recuperator of ventilation emissions with the intake of heat energy from ventilation emissions; thermal accumulators; individual heating station with weather-dependent automation; individual temperature regulators for heating devices; transition from metal pipes to plastic ones with insulation; bimetallic radiators for heating systems, etc. The issue of the durability of several possible options for the implementation of the heat supply system, complicated by the introduction of many different modern technologies, both in terms of the principle of operation and the achieved effect, is relevant. In this case, the use of element-by-element reliability calculation becomes much more complicated. First, the values of the failure rates for various types of modern equipment are usually trade secrets and are not provided by the manufacturer. Secondly, the excessive complication of modern heat-regulating devices does not allow making their element-byelement calculation of reliability due to the inaccessibility of information about a variety of patented solutions. Thirdly, for many new devices, sufficient operating time has not yet passed for the accumulation of statistical information sufficient to determine the value of the failure flow. The listed features stimulate the transition from element-by-element calculation of the reliability of heat supply systems to the calculation of reliability indices. This approach allows you to go to the integrated assessments of the reliability of the heating system of the building, to compare the predicted values of reliability and operating costs for various options for modernizing the building. Clarification of the algorithm and the transition to an index approach for assessing the reliability of heat supply systems will determine the flow of failures of system elements, which will allow assessing the reliability of the system and, according to the data obtained, take measures that will increase the longevity of heat supply
\end{abstract}

* Corresponding author: GuzhovSV@ mpei.ru 
systems. On the example of the heat supply system of an individual residential building, indices were determined for the current state of the system, as well as for two options for its modernization. It is shown that the complication of the building heat supply system does not always lead to a decrease in its reliability. Recommendations are formulated for the modernization of the building's heat supply system, leading to an increase in the reliability index.

\section{Introduction}

The development of an algorithm for calculating the integral index of the reliability of heat supply systems at the facilities of "green construction" in the Moscow region is an urgent task that requires the involvement of various fields of knowledge. Monitoring and dispatching a large number of separate power plants require special approaches to collecting, processing and analyzing information on the state of water supply and heat supply systems in order to ensure the reliability and stability of the equipment functioning.

System failures lead to the implementation of restoration work at the facilities, both through repairs and by replacing equipment. There may be penalties on the part of consumers for violation of the obligations of the heat supply organization for the supply of heat energy or in relation to the owner of the building - for the use of equipment that does not operate correctly.

To adapt the algorithm for calculating the reliability and assess the operational reliability of the equipment of heat points and heating networks, a review of modern literature on determining the reliability indicators for heat supply systems of buildings was carried out.

Monitoring should be carried out in relation to the indicators of the reliability and stability of the functioning of the main and auxiliary equipment of buildings, subject to the regularity of the implementation of maintenance. Since the equipment of heating points and networks inside the building is the most typical, the solutions obtained in the generalization and assessment of information about the current technical state of heat supply systems of buildings and the conditions of their functioning can be widely used for groups of similar buildings in the Moscow agglomeration.

The result of the project will make it possible to identify priorities for the implementation of measures aimed at improving the reliability of construction facilities; to increase the efficiency of the selection of the structure of the energy systems of buildings, taking into account the reliability criteria.

\section{Materials and methods}

The problem of calculating the operational reliability [1] in the general case can be solved on the basis of several approaches. In some cases, it is possible to determine the probability of failure of the heat supply system functioning on the basis of the exponential distribution model [2], [3], [4]. The disadvantages of this approach include the complexity of using separately for subsystems consisting of many components.

Another way is the step-by-step calculation of the reliability index [5] based on the method of the inductive logical approach "from particular to general". The method is not suitable for use in systems with many modern engineering solutions, due to the unavailability of data on failure rates for many elements.

A known method for calculating the failure rate of heating networks [6]. The average probability of no-failure operation of a system consisting of series-connected elements is taken equal to the product of the probabilities of no-failure operation: 


$$
P_{c}=\prod_{i=1}^{i=N} P_{i}=e^{-\lambda_{t} L_{1} \tau} \cdot e^{-\lambda_{2} L_{2} \tau} \cdot \ldots \cdot e^{-\lambda_{n} L_{n} \tau}=e^{-t \cdot \sum_{i=1}^{i=N} \lambda_{n} L_{n} \tau}=e^{\lambda_{c} \tau}
$$

Heat networks are represented as a series connection of elements, in which the failure of one of the entire set of elements leads to the failure of the entire system as a whole, which is not always true for the heat supply system of a building. Determination of the dependence of the flow parameter of failures on the pipe diameter is also used. It is shown in the literature that pipeline damage has little correlation with the pipe diameter indicator, the failure flow does not depend on the pipeline diameter [7].

The use of weather-dependent automation in combination with the individuality of heat points (IHP) increases not only the energy efficiency of the heat supply system but also increases the reliability of its operation [8], [9]. The disadvantage of the approach used in the literature on the basis of the exponential calculation model is the excessive enlargement of the consideration of the heat supply system, which does not allow for a sufficiently accurate calculation of the reliability of the system.

To calculate the reliability of the heat supply system of a building, it is proposed to use the reliability state index [10], based on an exponential distribution model combined with an approach that takes into account the aging of each of the elements of the heat supply system:

$$
\left\{\begin{array}{c}
\lambda(t)=\lambda=\text { const } \\
P(t)=e^{-\lambda t} \\
Q(t)=1-e^{-\lambda t} \\
P(t)=\frac{(\lambda t)^{k}}{k !} e^{-\lambda t} \\
\omega(t)=\lambda \\
t_{\mathrm{H} . \mathrm{o}}=t_{\mathrm{o}}
\end{array}\right.
$$

where $\lambda(\mathrm{t})$ - equipment failure rate; $Q(t)$ - equipment failure probability; $\omega(\mathrm{t})$ - average failure rate; $t_{\text {н.о }}, t_{\mathrm{o}}$ - MTBF and operating time to the first failure after recovery, respectively.

This approach allows you to determine the probability of failure-free operation for each of the subsystems: heating, ventilation, hot water supply (DHW). The value of the equipment failure rate is defined as:

$$
\lambda(\mathrm{t})=\frac{n}{N t}
$$

where $n$ is the number of out-of-order objects; $N$ - the total number of products; $t$ is the average number of trials.

It is understood that the heating, hot water supply and ventilation systems are connected in parallel, and the IHP is connected to them in series [11]. Based on the enlarged diagram (see Fig. 1), it becomes possible to determine the probability of failure-free operation of the system.

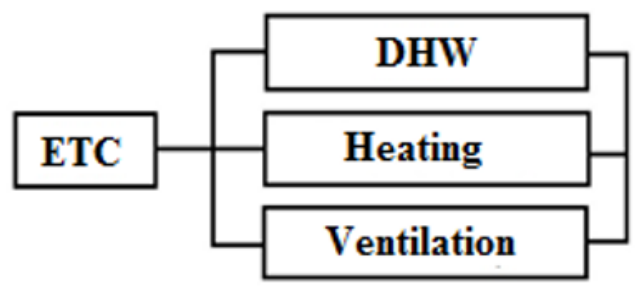

Fig. 1. Connection of heating, ventilation and DHW systems to the IHP.

The probability of failure of the DHW system is designated as $A_{\text {гвс }}$, heating system as

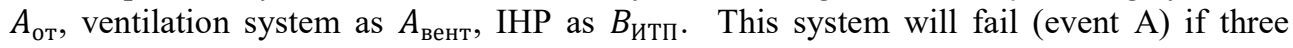
elements fail at the same time. Consequently, the failure of an element can be represented as 
the product of events $A_{\text {гвс }}, A_{\text {от }}, A_{\text {вент. }}$. Since the elements stop working independently of each other, then from the independence of events $A_{\text {гвс }}, A_{\text {от }}, A_{\text {вент }}$ we get:

$$
P(A)=1-\left(1-P\left(A_{\text {гвс }}\right)\right) \cdot\left(1-P\left(A_{\text {от }}\right)\right) \cdot\left(1-P\left(A_{\text {вент }}\right)\right)
$$

The system of serial connection "IHP" - "heating, ventilation, DHW" will fail (event B) if at least one of the elements fails. This state of the system can be described as the sum of events:

$$
P(B)=P\left(B_{\text {итп }}\right) \cdot P(A)
$$

For a more accurate assessment of the reliability of the heat supply system, it is necessary to consider each element separately.

The paper evaluates and predicts the reliability index of the heat supply system of an individual residential building built in 2000 . According to the design solution, the heat supply system consisted of an elevator, heating system, DHW and ventilation. The complex of devices under consideration includes a ventilation system consisting of pipelines, valves and a heater connected in series with each other. The building DHW system consists of two mainline taps connected in parallel with each other. The building's heating system consists of 10 heating devices, which are located 5 on each floor. A two-pipe heating system is used [12]. In 2013, the elevator was replaced with an IHP, and in 2021 a heat pump was added to the heat supply scheme, the heat energy from which is used in the heating system [13]. Elements such as piping, shut-off valves, radiators, DHW valves and a ventilation system heater have not been replaced or repaired.

Let us determine the values of the building reliability for the following options for the layout of the building heat supply system:

I. In the period in 2000. until 2021, the building's heating system has not undergone any changes.

II. In 2015, the elevator was replaced with an IHP, no more changes were made to the scheme until 2021;

III. In 2015, the elevator was replaced with an IHP. Also in 2021, a heat pump was installed with the return of thermal energy to the heating system of the building, which has been in operation for 2 months.

IV. Apart from the installation of the heat pump in 2021, no changes were made.

In this work, assumptions are made about the implementation of a closed, independent heat supply system in the building under consideration [14]. It is advisable to calculate the reliability of the IHP by the elements included in it, combined into a whole [15]. This method makes it possible to compare the units of units in terms of their reliability in order to improve their operation. Similarly, the assessment of the reliability of heating systems, DHW, heating and their constituent elements was carried out.

The substation consists of many elements included in it. Calculating each element is a process with many unknowns inaccessible. Therefore, to assess the reliability of the substation, assumptions were made about the known layout of the IHP. The enlarged connection diagram is shown in Fig. 2.

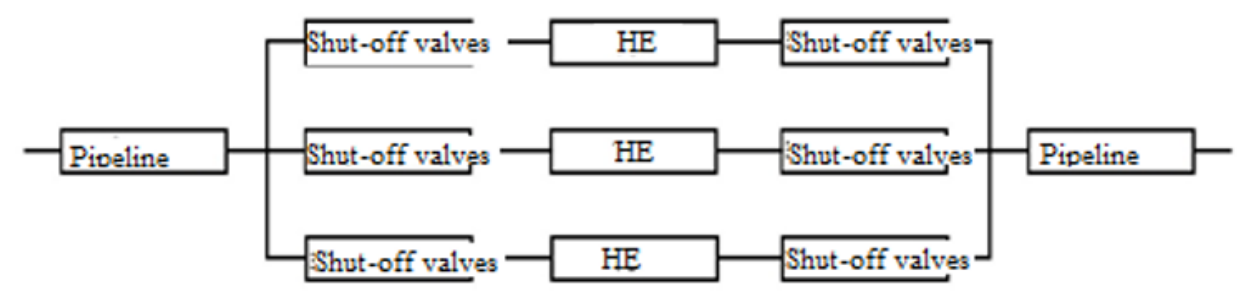

Fig. 2. Connection of IHP elements. 
For convenience, you need to split the proposed scheme into 3 sections (Fig. 3). Each section consists of elements connected in series.

Let us designate $A_{1}$ as the probability of failure of a section consisting of two valves connected in series and one heat exchanger. This section will fail (event $A_{1}$ ) if three elements fail simultaneously. The system consists of three such sections (DHW, heating, ventilation) connected in parallel with each other. The probability of each site will be, respectively, equal to $A_{1}, A_{2}, A_{3}$.

$$
\begin{aligned}
& P\left(A_{1}\right)=P\left(A_{\text {з.а }}\right) \cdot P\left(A_{\text {т.о. }}\right) \cdot P\left(A_{\text {з.а }}\right) \\
& P\left(A_{2}\right)=P\left(A_{\text {з.а }}\right) \cdot P\left(A_{\text {т.о. }}\right) \cdot P\left(A_{\text {3.а }}\right) \\
& P\left(A_{3}\right)=P\left(A_{\text {з.а }}\right) \cdot P\left(A_{\text {т.о. }}\right) \cdot P\left(A_{\text {з.а }}\right)
\end{aligned}
$$

Since the elements stop working independently of each other, then proceeding from the principle of independence of events, we formulate the formula:

$$
P(A)=1-\left(1-P\left(A_{1}\right)\right) \cdot\left(1-P\left(A_{2}\right)\right) \cdot\left(1-P\left(A_{3}\right)\right)
$$

This system will not work (event $B$ ) if at least one of the elements fails. This state of the system can be described as the sum of events:

$$
P(B)=P\left(B_{\text {итп }}\right) \cdot P(A) \cdot P(A) \cdot P\left(B_{\text {тр }}\right)
$$

To assess the reliability of the heating system, you need to decompose it into the following elements: valves, heat exchanger, pipeline, pumps, heating radiators. The diagram (Fig. 3) is simplified since only one heating radiator is considered. If this calculation is applied for a specific heating system, then all heating radiators will be taken into account.

where: 1, 6 - Shutoff valves; 2 - Heat-exchange apparatus; 3 - Pipeline; 4 - Pump; 5 Heating radiator;

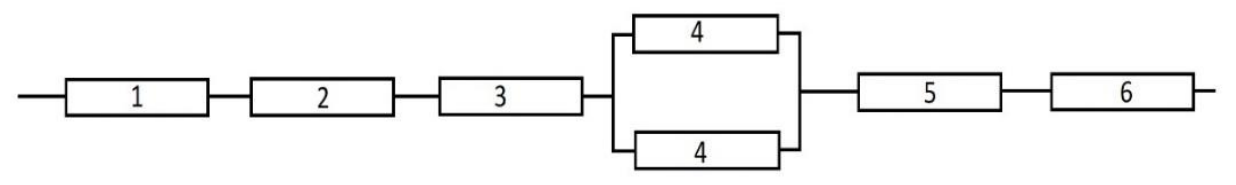

Fig. 3. Connection diagram of heating elements.

Let's designate the probability of failure of a section, which consists of 2 parallelconnected elements, as $A_{\mathrm{H}}$. Since the elements stop working independently of each other, then from the independence of events we get:

$$
P\left(A_{1}\right)=1-\left(1-P\left(A_{\mathrm{H}}\right)\right) \cdot\left(1-P\left(A_{\mathrm{H}}\right)\right)
$$

Stop valves, heat exchanger, pipeline, pumps, heating radiators are connected in series. This section will fail (event $(B)$, if six elements fail simultaneously:

$$
P(B)=P\left(B_{\text {3.а. }}\right) \cdot P\left(A_{1}\right) \cdot P\left(B_{\text {т.о. }}\right) \cdot P\left(B_{\text {тр. }}\right) \cdot P\left(B_{\text {р.о. }}\right) \cdot P\left(B_{\text {3.а. }}\right)
$$

The calculation of DHW and ventilation systems is performed in the same way. Fig. 4 and Fig. 5 show the DHW and ventilation connection diagrams.

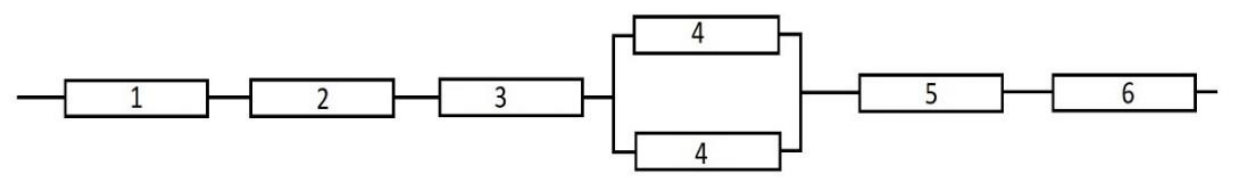

Fig. 4. DHW connection diagram, where 1, 2, 3, 4, 6 see above, 5 - taps. 


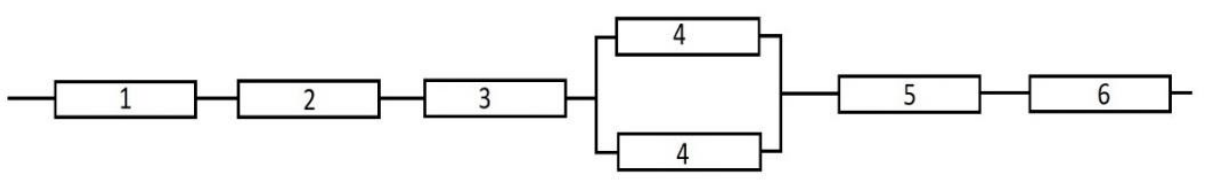

Fig. 5. Ventilation connection diagram, where 1, 2, 3, 4, 6 see above, 5 - heater.

\section{Results}

Based on formulas (4)-(12) and the values of the failure rate (Table 1) it becomes possible to determine the calculated reliability index of the heat supply system of an individual residential building at the time of May 1, 2021 (Table 2). The values of the calculated reliability index of the heat supply system of a building of individual construction with various options for modernization are given in Table 2

Table 1. Failure rate [7].

\begin{tabular}{|l|l|c|}
\hline No. & \multicolumn{1}{|c|}{ Item name } & Item failure rate \\
\hline 1 & Pipeline & $1.1 \times 10-6$ \\
\hline 2 & TC & $15 \times 10-6$ \\
\hline 3 & Shutoff valves & $6.5 \times 10-6$ \\
\hline 4 & Pump & $3.3 \times 10-6$ \\
\hline 5 & Heating radiator & $0.5 \times 10-6$ \\
\hline
\end{tabular}

Table 2. The calculated index of the reliability of the heat supply system of a building of individual construction with various options for modernization by the time of May 1, 2021.

\begin{tabular}{|l|c|}
\hline \multicolumn{1}{|c|}{ Option No. } & $\begin{array}{c}\text { Design index } \\
\text { of reliability }\end{array}$ \\
\hline $\begin{array}{l}\text { I. In the period in } 2000 \text { until 2021, the building's heating system was not subject } \\
\text { to changes }\end{array}$ & 0.857 \\
\hline $\begin{array}{l}\text { II. In 2015, the elevator was replaced with an IHP, no more changes in the scheme } \\
\text { were made until 2021 }\end{array}$ & 0.414 \\
\hline $\begin{array}{l}\text { III. In 2015, the elevator was replaced with an IHP. Also in 2021, a heat pump } \\
\text { was installed with the return of thermal energy to the heating system of the } \\
\text { building, which has been in operation for 2 months. }\end{array}$ & 0.998 \\
\hline IV. No changes were made except for the installation of the heat pump in 2021 & 0.967 \\
\hline
\end{tabular}

Despite the fact that the heat supply system with an elevator is outdated, its reliability remains quite high. A more energy-efficient heat supply scheme for a building with IHP and weather-dependent automation is implemented with the addition of many elements, which reduces the reliability of the entire system.

Connecting a heat pump to the IHP will increase the reliability of the heat supply system. Cheapness, small size and ease of installation are the advantages of this system. The pumps and heat exchanger can be located in the basement of the building.

\section{Discussion}

Assessment of heat supply systems will allow predicting their durability and analyzing changes in reliability when introducing energy-saving measures.

As can be seen from the calculation, the introduction of IHP reduced the reliability of the heat supply system, since many elements connected in series appeared in it. The solution to 
connect the heat pump will greatly increase the reliability of the system since it is connected in parallel.

Calculations for determining the main characteristics of the reliability of heat supply systems show that the reliability of the system depends on its scheme and the reliability of the elements.

A reliable element is a new, not always expensive, device that has proven itself in the market and has numerous references. The use of untested, cheap devices increases the risk of premature failure of the device and the entire system.

In order to improve the reliability of heat supply systems, it is also possible to increase the number of parallel connections. The more parallel connections, that is, the more redundant elements are used in the heating system, the more reliable the system becomes. But item reservation is not always possible. First, due to the increased economic costs of purchasing additional devices. Secondly, there is not always enough space for the installation of additional elements.

The investigation was carried out within the framework of the project "Integral index of energy systems of buildings based on groups of indicators of efficiency and reliability" with the support of a grant from NRU "MPEI" for implementation of scientific research programs "Energy", "Electronics, Radio Engineering and IT", and "Industry 4.0, Technologies for Industry and Robotics in 2020-2022".

\section{References}

1. GOST 27.002-89. Nadezhnost' v tekhnike. Osnovnye ponyatiya. Terminy i opredeleniya. Nadezhnost' v tekhnike (IPK Izdatel'stvo standartov, 2002)

2. S.P. Timoshenkov, Osnovy teorii nadezhnosti: uchebnik i praktikum dlya vuzov (2021)

3. M.E. Orlov, V.I. SHarapov, Santekhnika, otoplenie, kondicionirovanie, 2(170), 48 (2016)

4. M.V. Posashkov, N.I. Ishtykova, Open innovation. Sbornik statej V Mezhdunarodnoj nauchno-prakticheskoj konferencii, 42 (2018)

5. L.S. Maksyutova, Fiziko-matematicheskie i tekhnicheskie nauki kak postindustrial'nyj fundament evolyucii informacionnogo obshchestva: sbornik statej Mezhdunarodnoj nauchno - prakticheskoj konferencii, 141 (2017)

6. S.V. CHicherin, V.M. Lebedev, S.V. Gluhov, Povyshenie energoeffektivnosti ob"ktov energetiki i sistem teplosnabzheniya: materialy vserossijskoj nauchno-tekhnicheskoj konferencii s mezhdunarodnym uchastiem, 47 (2017)

7. YU.N. Zvonareva, YU.V. Van'kov, Izvestiya VUZov. Problemy energetiki, 1-2 (2017)

8. I.N. Zapol'skaya, YU.V. Van'kov, SH.G. Ziganshin, A.F. Valeev, O.I. Zverev, Vestnik KGEU, 4(36) (2017)

9. S.A. Maksakov, Izvestiya TulGU. Tekhnicheskie nauki, 2 (2020)

10. S.V. Nikonorov, Vestnik YUUrGU. Seriya: Stroitel'stvo i arhitektura, 35(168) (2009)

11. V.A. Bogatyrev, Informacionnye sistemy i tekhnologii. Teoriya nadezhnosti: uchebnoe posobie dlya bakalavriata i magistratury (YUrajt, 2018)

12. Kak vybrat' optimal'nuyu skhemu razvodki otopleniya doma, https://inredhome.ru/news/otoplenie

13. E.G. Avdyunin, Istochniki i sistemy teplosnabzheniya. Teplovye seti i teplovye punkty: uchebnik (Infra-Inzheneriya, 2019)

14. A.S. Zemlyakov, Innovacionnaya nauka, 12-2 (2015)

15. A.P. Svincov, T.V. Skripnik, M.T. Gusamov, T.K. Krivoshapkina, Stroitel'naya mekhanika inzhenernyh konstrukcij i sooruzhenij, 2 (2017) 